\title{
IJ21CE
}

\section{THE IMPACT OF COVID-19 ON THE IMPROVEMENT OF TEACHING SKILLS ON PROBLEM-BASED LEARNING (PBL)}

\author{
IMPACTO DE LA COVID-19 EN LA MEJORA DE LAS COMPETENCIAS \\ DOCENTES SOBRE EL APRENDIZAJE BASADO EN PROBLEMAS (ABP)
}

\author{
JeLENA ZASCERINSKA ${ }^{*_{1}}$, LUdMILA ALEKSEJEVA*, MIHAILS ZASCERINSKIS*, \\ OLGA GUKOVICA* \& ANASTASIJA ALEKSEJEVA*
}

${ }^{*}$ Centre FOR Education And InNOVAtION RESEARCH (LATVIA)

\begin{abstract}
Teaching problem solving skills is essential for the continuous training of university teachers. However, the COVID-19 pandemic has had a dramatic effect on the improvement of teachers' skills in problembased teaching. The aim of the paper is to explore the impact of the COVID-19 pandemic on the enhancement of university teachers' skills in problem-based teaching underpinning the implementation of the empirical analysis carried out within an international project. The research is based on the methodology of the system of the external and internal perspectives. The exploratory research was employed in the empirical study. The survey was conducted in July-August 2020. The sample contained 18 respondents ( 3 females and 15 males). The age of the respondents ranged from 30 to 70 years old. The data were processed by making use of the content analysis. The content analysis of the data from the survey consists of the content structuring and summarizing. The COVID-19 pandemic has had a significant impact on the external perspective of the enhancement of university teachers' skills on problembased teaching within the international project as the project participants consider the COVID-19 pandemic as a challenge. Another finding is that the negative impact of the COVID-19 pandemic on the enhancement of university teachers' skills in problem-based teaching within the international project prevails. The theoretical finding is the newly defined structural elements of problem solving, namely challenge, opportunities, gains and possibilities, analysed within the methodology of the development of the system of the external and internal perspectives. The empirical study shows that the COVID-19 pandemic has negatively impacted the enhancement of university teachers' skills in problem-based teaching within this international project.
\end{abstract}

Keywords: Higher Education, COVID-19, University Teachers, Problem Solving Skills, International Projects.

\section{RESUMEN}

La enseñanza de habilidades para la resolución de problemas se basa en el desarrollo profesional continuo de los profesores universitarios. Sin embargo, la pandemia de COVID-19 ha impactado enormemente en la mejora de las habilidades de los maestros en la enseñanza basada en problemas. El objetivo del trabajo es explorar el impacto de la pandemia COVID-19 en la mejora de las habilidades de la enseñanza basada en problemas de los profesores universitarios. La investigación se basa en la metodología del sistema de las perspectivas externa e interna. La investigación exploratoria se empleó en

\footnotetext{
1 Corresponding author: Jelena Zascerinska. Latvia. e-mail: iizi.info@inbox.lv
} 
el estudio empírico. La encuesta se realizó en julio-agosto de 2020 y participaron 18 encuestados (tres mujeres y 15 hombres) de entre 30 y 70 años. Los datos se procesaron mediante análisis de contenido. El análisis de contenido incluyó el análisis de contenido estructurado y resumido. Resultados principales: La pandemia de COVID-19 impactó significativamente la perspectiva externa de la mejora de las habilidades de los profesores universitarios en la enseñanza basada en problemas dentro del proyecto internacional, ya que los participantes del proyecto consideran la pandemia de COVID-19 como un desafío. Otro hallazgo es que prevalece el impacto negativo de la pandemia COVID-19 en la mejora de las habilidades de los profesores universitarios en la enseñanza basada en problemas dentro del proyecto internacional. Conclusiones: El hallazgo teórico son los elementos estructurales de resolución de problemas recientemente definidos, a saber, desafío, oportunidades, ganancia y posibilidad, analizados dentro de la metodología del desarrollo del sistema de las perspectivas externa e interna. El estudio empírico muestra que la pandemia de COVID-19 afectó negativamente la mejora de las habilidades de los profesores universitarios en la enseñanza basada en problema

Palabras clave: Educación superior, COVID-19, Docentes universitarios, Habilidades para la resolución de problemas, Proyectos internacionales

\section{Introduction}

Problem solving skills are one of the Top 10 Skills of 2025 (World Economic Forum, 2020b). Further on, problem solving has stayed at the top of the agenda with year-on-year consistency (World Economic Forum, 2020b).

Higher education still plays the important role in delivering problem solving skills to prospective employees despite the initiated discussion on decisive tackling long delayed improvements to education (World Economic Forum, 2020b) including higher education. Moreover, Higher Education has been among the top 20 starter sectors for young people (World Economic Forum, 2020b).

The key actors in delivering problem solving skills to prospective employees within higher education are university teachers (Ahrens \& Zaščerinska, 2014a). The development of a highquality higher education and, consequently, teaching problem solving skills is based on the continuing professional development of university teachers (Zascerinska, 2010a). The professional development of university teachers includes their participation in informal and nonformal education, international projects and knowledge dissemination, i.e. scientific publications (Ahrens et al., 2019).

As the advancement of the internationalization of the higher education improves the quality of higher education and research (NIEA, 2020), university teachers' participation in international projects serves as a tool for the enhancement of their skills in problem-based teaching as depicted in Figure 1.

\section{Higher Education}

University teacher' professional development
International projects

Figure 1. The relationship between the higher education, university teachers' professional development and international projects for the enhancement of university teachers' skills in problem-based teaching 
It should be noted that university teachers' participation in international projects also implies university teachers' contribution to the project management.

However, as the article's authors have observed, the outbreak of the coronavirus ('COVID-19 crisis') to the scale of a global pandemic has tremendously impacted the higher education delivery, university teachers' participation in professional development activities, implementation of international projects and other aspects related to higher education. On the one hand, teachers had to shift from on-campus teaching to only online teaching and online learning that required them to use a variety of digital platforms, tools and resources to prepare educational materials and tasks based on the implementation of new approaches (Eickelmann \& Gerick 2020). Beyond instructional goals, teachers had to communicate with their students, maintain the students' work in groups as well as ensure the students' inclusion into the educational process (König, JägerBiela, \& Glutsch, 2020). On the other hand, since March 2020 teachers have been invited for a teacher training to acquire effective online teaching methods (Lieberman, 2020). The professional development was the focus of that effort. However, the involvement of the overloaded teachers into the training participation proceeded with many difficulties (Lieberman, 2020) as, according to the teachers' opinión, twice more time is required for remote teaching delivery (Ahrens, et al., 2015).

The development of the individual is in the focus of education (Maslo, 2007; Robbins, 2007), including higher education. The term "development" in pedagogy means qualitative changes of knowledge, skills and attitudes in the teacher growth and socialization while focusing on the enrichment of human potential and features in the human (Žogla, 2007).

The professional development is one of the aspects in development (Панов, 2007). Consequently, the professional development of the personality (i.e. university teachers) is identified as part of the individual development (Zascerinska, 2010a). In pedagogy, the professional development is defined as a qualitative change, that proceeds in the inclusive professional process, and efforts for sharpening teacher professional activity that is based on the professional conditions, opportunities, and circumstances, and aligned to the needs of society (Kacapa, 1999). The professional development is built on the professional learning (Zascerinska, 2010a). Consequently, the professional learning is determined as a possibility for one's continuing professional development (Zascerinska, 2010a). The professional learning is also regarded as lifelong learning (European Commission 2004).

The professional development and learning is a problem-situation (Zascerinska, 2010a). The development, including professional development, and learning is based on solving a contradiction (Čehlova 2002) as shown in Figure 2.

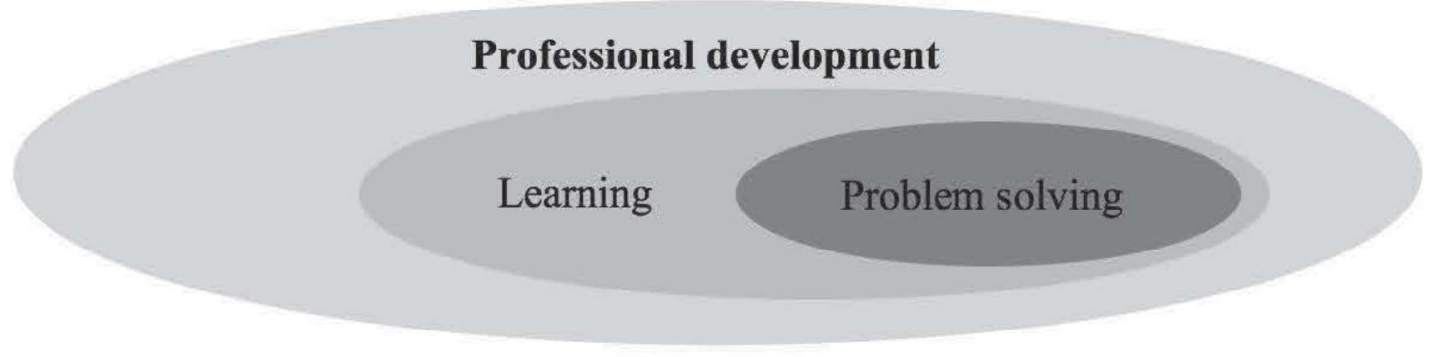

Figure 2. The relationship between professional development, learning and problem solving

A contradiction means two incompatible requirements set to one phenomenon or, in other words, element/subject/ etc (Sokol, 2002, p. 4). In regard to individuals, a contradiction creates contradictory individual needs, namely, the individual's necessity in change and stability (Grabovska 2006, p. 40). A contradiction is also observed as a problem situation (Sokol 2007, p. 70) and a problem (Сорокин 1977, р. 131). 
A problem is defined to be a challenge and an opportunity (Sālsberg 2003, p. 35). However, in this definition, the external perspective prevails. As an alternative, from the internal perspective, a problem is identified as a hope and possibility (Zaščerinska \& Zaščerinskis, 2012) based on the curriculum practice (Portelli 2010, p. 12). The curriculum implementation is centred on the process of teaching and learning (Zaščerinska, Zaščerinskis, 2012). Figure 3 illustrates the novel definition of the term "problem" from the external and internal perspectives.

\begin{tabular}{cc}
\hline External Perspective & Internal Perspective \\
\hline Challenge and opportunity & Gain and possibility \\
\hline The system of the external and interna oerspectives \\
\hline
\end{tabular}

Figure 3. The definition of the term "problem" from the external and internal perspectives

Individual's development proceeds in the social-cultural environment, while the professional development takes place in the professional environment (Zaščerinska, 2010b). The professional environment is a part of the social-cultural environment (Zaščerinska, 2010a). The professional environment is aimed at preparing a teacher who is able to proceed in life and to make the life and the world better and more attractive (Maslo, 2006). A teacher develops in the professional environment that is conventionally built on the diverse open professional problem situations (Zaščerinska, 2010a). The professional environment is based on the principles of mutual sustainability, complementarity and reflexivity (Zaščerinska, 2010a). The professional environment proceeds within the object-regulation, other-regulation and self-regulation as disclosed in Table 1 (Zaščerinska, 2010a).

Table 1.

Conditions for the teacher professional development in the socio-cultural context (Zaščerinska, 2010a, p.24)

\begin{tabular}{|c|c|c|}
\hline \multicolumn{3}{|c|}{ Professional Environment } \\
\hline External Perspective & & ternal Perspective \\
\hline Interpersonal dialogue & Study cultural dialogue & Individual's internal dialogue \\
\hline Object-regulation & egulation & Self-regulation \\
\hline Establishing social purposes, & Establishing joint purposes, & Establishing personal purposes, \\
\hline $\begin{array}{c}\text { social interaction planning and } \\
\text { organizing }\end{array}$ & $\begin{array}{c}\text { collaboration planning and } \\
\text { organizing }\end{array}$ & $\begin{array}{l}\text { individual planning and } \\
\text { organizing }\end{array}$ \\
\hline Social decision making & Joint decision making & Individual decision making \\
\hline External evaluation & $\begin{array}{l}\text { Mutual evaluation and self- } \\
\text { evaluation }\end{array}$ & Self-evaluation \\
\hline
\end{tabular}

The conditions, namely developing the system of the external and internal perspectives, teacher interaction and reflection shape opportunities for the teacher professional development. These opportunities enable teachers to be mobile, to learn from the others' experiences and to work qualitatively (Maslo, 2006).

The essence and sequence of the problem solving based on the Vygotsky's zones of development (Vigotskis, 2002, p. 275) proceeds from teaching in Phase 1 through peer-learning in Phase 2 to learning in Phase 3 as depicted in Figure 4 (Zaščerinska \& Ahrens 2010, p. 185). In other words, the teachers' professional development/growth proceeds in the three phases, namely from Phase 1 Teachers' professional training through Phase 2 Teachers' professional peer-learning and to Phase 3 Teachers' professional learning. 


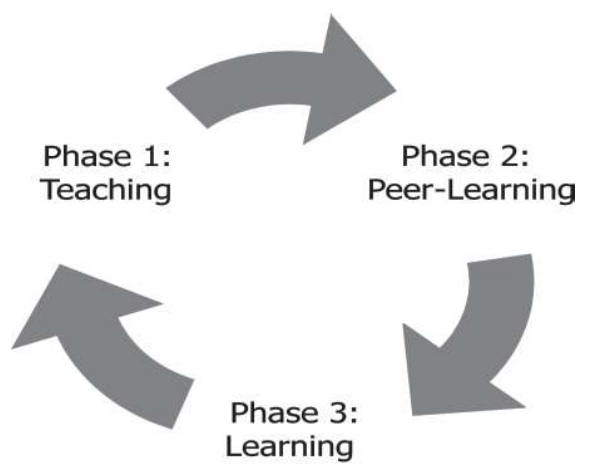

Figure 4. Three phases of the problem solving

Phase 1 is aimed at organizing a safe environment for all the participating students. This phase is implemented in a frontal way in order to involve the students to participate in the activitiy. Phase 2 is designed for the students' analysis of an open professional problem situation and their search for a solution (Zaščerinska \& Ahrens 2010). This phase is based on the students' peerlearning (Zaščerinska \& Ahrens 2010). Phase 3 focuses on the students' self-regulation. The selfregulation includes the assessment of the process and self-evaluation of the results. Students' self-evaluation is presented by the student and discussed with all the other students by the end of each class.

Table 2 presents the approaches and phases applied to the teaching and learning of problem solving in higher education (Zaščerinska \& Zaščerinskis, 2012).

Table 2.

Approaches and phases used for the teaching and learning of problem solving in higher education

\begin{tabular}{ccl}
\hline Number & \multicolumn{1}{c}{ Approach } & \multicolumn{1}{c}{ Phases } \\
\hline 1. & Learning cycle (Maslo, 2007, p. 59) & 1. Formulating a question; \\
& & 2. The analysis of experience of learning planning; \\
& 3. Drawing a conclusión.
\end{tabular}

2. Research as a systematic process of inquiry consisting of three elements (Nunan, 1992, p. 3)

1. A question, problem, or hypothesis;

2. Data, and analysis;

3. Interpretation of data.

3. Creative act (Мельникова, 2003, р. 1. Formulating a question; 234-235)

2. Solving a problem;

3. Choosing and examining the decision.

4. Problem solving (Sokol, 2002, p. 12) in the interpersonal system, thereby developing the system of the external and internal perspectives

5. Systemic problem solving in the frame of the Theory of Inventive Problem Solving developed by Altsguller (Sokol, 2002, p. 9)

1. To recognize the contradiction underlying the given problem; and

2. To resolve the contradiction constructively.

1. Problem as the system development in the past, present and future;

2. Problem as the sub-system development in the past, present and future; and

3. Problem as the above-system development in the past, present and future.

6. Accepting and obtaining values 1. Value cognition; 
defined as interiorization (Лобанов, 2004, p. 39)

7.

Constructive process of the socialcultural learning experience (Tilla, 2003, p. 37; Žogla, 2007, p. 2)

8. Organizing social-cultural learning (Tilla $a, 2005$, p. 83)
2. Translation of the value information into one's own individual language;

3. Subject activity that results in the value accepting or rejecting;

4. Including the value into the individual's own system of values;

5. A personality change as a result of the value acceptance or rejection.

1. Reconstruction: to call for a part of one's experience in the memory to be revealed and changed into the new;

2. Deconstruction: to re-arrange one's experience, to supplement it with the new;

3. New construction: to create and realize a part of the new experience.

1. Preparing;

2. Activity; and

3. Evaluation.

The organization of the problem solving process as shown in Figure 4 is advantageous (Zaščerinska, 2010c). An advantage is the widening of the opportunities for every teacher or student to construct his/her social experience (the experience in social interaction and cognitive activity) (Zaščerinska, 2010c). The social experience is a significant aspect of learning (Zaščerinska, 2010c). Another advantage is the promotion of the opportunities for self-realization (Zaščerinska, 2010c).

The definition of the term "problem" from the external and internal perspectives shown in Figure 3 as well as the essence and sequence of the problem solving based on the Vygotsky's zones of development as illustrated in Figure 4 allow the authors to identify the logics and sequence of the process of the teacher profesional development. The teachers' professional development/growth proceeds in the three phases, namely from Phase 1 Teachers' professional training through Phase 2 Teachers' professional peer-learning and to Phase 3 Teachers' professional learning. All the three phases of the process of the teachers' professional development are important (Ahrens et al., 2021). That means that, despite the growing popularity of peer-learning that prevails in the modern organization of the training process, all the three phases should be included in the process of the teachers' professional development (Ahrens et al., 2021). Teachers' participation only in Phase 1 Training and Phase 2 Peer-learning cannot be evaluated as teachers' professional development. Moreover, the training process should follow the indicated sequence of the phases of the process of teachers' professional development: from Phase 1 Teachers' professional training through Phase 2 Teachers' professional peer-learning and to Phase 3 Teachers' professional learning (Ahrens et al., 2021).

The authors also re-define university teachers' and students' problem solving skills as the ability and experience to turn a challenge or opportunity belonging to the external perspective into a gain and possibility related to the internal perspective, or, in other words, an individual solves a problem if $s /$ he is able to transform a disadvantaged situation (the external perspective) into a favorable gain (the internal perspective). Further on, the external perspective in the problem solving is considered by the article authors as a negative phenomenon, while the internal perspective - as a positive one. This can be explained by the article authors as following: if university teachers and students only solve the external problems without turning them into gains and possibilities, then, their professional development is not enhanced and, consequently, can be negatively evaluated. If university teachers and students are able to turn challenges into gains, 
then, their professional development is qualitatively changed and, accordingly, is positively evaluated.

\section{Objectives and hypotheses}

The enabling research question is put forward: What is the impact of the COVID-19 pandemic on the enhancement of university teachers' skills in problem-based teaching within international projects?

The aim of the paper is to explore the impact of the COVID-19 pandemic on the enhancement of university teachers' skills in problem-based teaching underpinning the implementation of the empirical analysis carried out within an international project.

The hypotheses $(\mathrm{H})$ have been formulated as following:

H1: Teachers' professional development/growth proceeds in the three phases, namely from Phase 1 Teachers' professional training through Phase 2 Teachers' professional peer-learning to Phase 3 Teachers' professional learning.

$\mathrm{H} 2$ : Teachers consider problem solving as the system of the external and internal perspectives, namely a challenge and opportunity (the external perspective) and a gain and possibility (the internal perspective).

H3: Teachers perceive problem solving positively.

\section{Methodology}

\subsection{Design}

The present work is based on the methodology of the system of the external and internal perspectives as demonstrated in Figure 5 (Ahrens \& Zaščerinska 2010, p. 181).
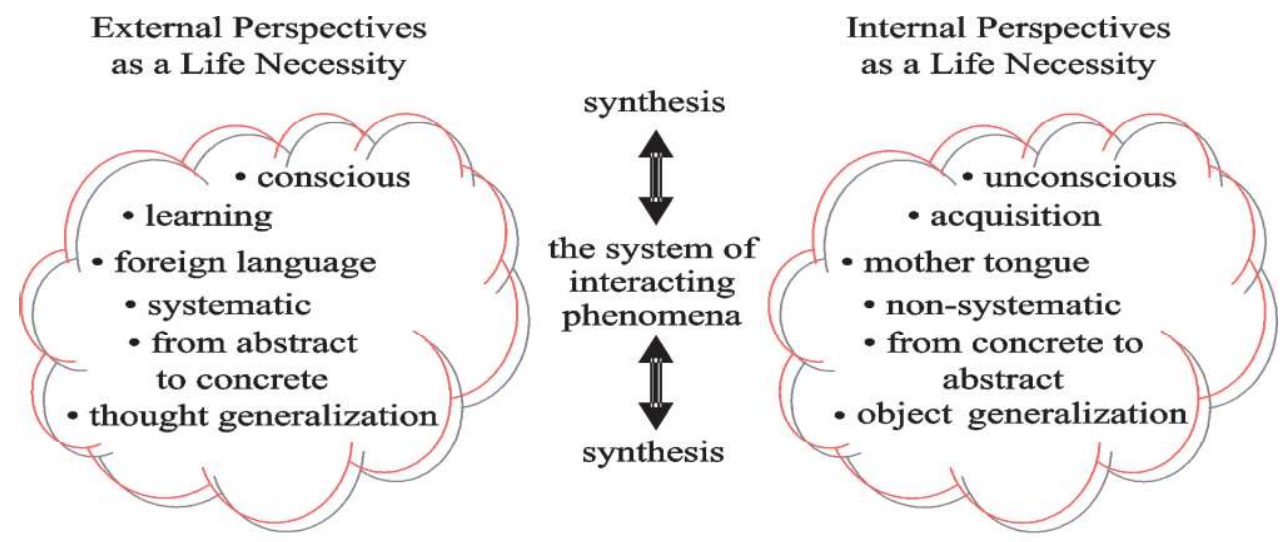

Figure 5. The development of the system of the external and internal perspectives

The methodology of the system of the external and internal perspectives proceeds from the external perspective through the interaction between the external and internal perspectives to the internal perspective (Zaščerinska, 2011). In education, the methodology of the system of the external and internal perspectives is interpreted as the individual's own system of the external and internal perspectives (Zaščerinska, 2010a). Moreover, the individual's own system of the external and internal perspectives is a complex open system (Zaščerinska, 2010a).

The design of the present empirical study is built on the purpose, question, sample, and methodology of the study (Bassus et al., 2014). 


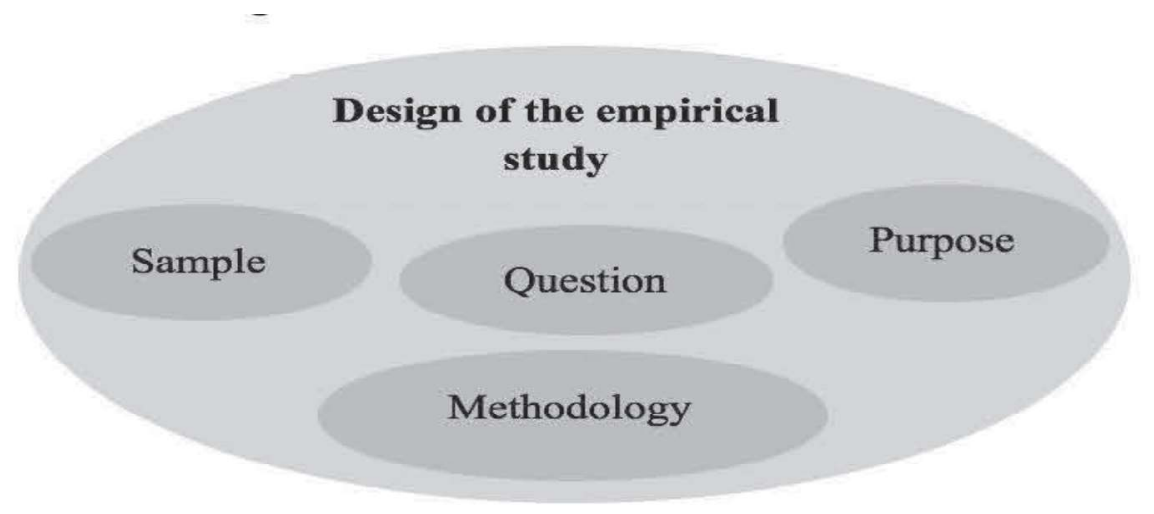

Figure 6. The elemenst of the design of the empirical study

The international project, used for the empirical study, intended to support the capacity building of the university teachers from the partner universities from both European and Third countries. In total, nine institutions in the field of higher education represented the partnership of the project. Five intitutions were from different European countries, and four universities belonged to a Third country. The project was focused on the joint development of new Master programmes in the field of engineering (electrical, building, energy, etc). The professional development of the university teachers was organized in both European and Third countries, thereby teachers' mobilities were an important element for their professional learning.

The interpretive research paradigm was used in the study. The interpretive paradigm is featured by the researcher interest in a phenomenon. The interpretive paradigm is characterized by the researcher practical interest in the research question (Cohen, Manion, \& Morrison, 2003). The interpretive paradigm is aimed at analysing the social construction of the meaningful reality. Meanings emerge from the interpretation. The researcher is the interpreter (Ahrens et al., 2018).

The data were collected by the implementation of the survey method. The survey was part of the internal quality assurance process of the project management. In addition to the regular questions concerning the project progress, a number of additional questions relating to the project partners' experiences during the COVID-19 pandemic were addressed. The objective of this part of the survey was to gather information, about the consequences of health, work or travel restrictions in the context of the international project. The survey was hosted on the online portal of Lime Survey. The link was not open to all the project participants. The link was provided to the participants acting as the partner representatives during the past months. In total, 16 individuals received a link to the online portal of Lime Survey. These 16 individuals were invited to share the link with the other team members of their partner institution.

The survey was based on a questionnaire. The questionnaire was composed of the following questions:

1. Have you or your institution experienced restrictions in work life due to the COVID-19 pandemic?

2. Have the effects of the COVID-19 pandemic led to changes in your project budget calculation?

3. In how far has the work in general in the project been effective and efficient?

4. How do you consider the communication between the project partners?

5. Are you optimistic that the project will be concluded successfully in time?

The questionnaire respondents were expected to describe the situation, they experienced, in their own words. The questionnaire did not imply any use of the Likert scale.

The survey was distributed among all the project partners involved in order to obtain a complete overview and the broadest possible quantitative basis. 


\subsection{Participants}

In total, 18 individuals participated in the survey, thus constituting a very sound quantitative basis to obtain a general impression on the project group's experience as a whole. Each of the nine partner institutions was represented by two respondents. The sample included 15 male respondents and three female respondents. Accroding to the World Economic Forum (2020a), females are still under-presented in many professional areas including international projects. Table 3 and Table 4 show the selected sample sex and age, respectively.

Table 3.

The selected sample sex

\begin{tabular}{ccc}
\hline Respondents' gender & $\begin{array}{c}\text { Number of } \\
\text { respondents }\end{array}$ & Percentage (\%) \\
\hline Male & 15 & $83.3 \%$ \\
Female & 3 & $16.6 \%$ \\
\hline
\end{tabular}

Table 4.

The selected sample age

\begin{tabular}{ccc}
\hline Respondents' age & $\begin{array}{c}\text { Number of } \\
\text { respondents }\end{array}$ & Percentage (\%) \\
\hline $36-50$ & 6 & $33.3 \%$ \\
$51-65$ & 7 & $38.8 \%$ \\
$66-\ldots$ & 5 & $27.7 \%$ \\
\hline
\end{tabular}

Table 5 reveals the range, mean and standard deviation of the age of the selected sample.

Table 5 .

The range, mean and standard deviation of the age of the selected sample

\begin{tabular}{ccc}
\hline $\begin{array}{c}\text { Range of the respondents' } \\
\text { age }\end{array}$ & $\begin{array}{c}\text { Mean of the } \\
\text { respondents' } \\
\text { age }\end{array}$ & Standard Deviation \\
\hline 34 & 53 & 10 \\
\hline
\end{tabular}

The analysis of the range of the respondents' age in the selected sample results in 34 . The range of 34 in the selected sample indicates a greater dispersion in the data or, in other words, how far the values of the data set are spread out. The average age (the mean) of the selected sample is 53 years old. The standard deviation of the selected sample is 10. This large standard deviation means that the values in the data set are farther away from the mean.

Nevertheless, three participants did not complete the entire survey or did not answer all the questions, therefore the number of the respective total answers to the particular questions may deviate from the total.

\subsection{Procedure}

The present empirical study was carried out in July-August 2020 within an international project funded by Erasmus+. The university teachers' professional development included university teachers' participation in the project meetings composed of different activities: workshops, seminars, conferences, dissemination events, industry and business on-site visits, cultural programme in a host country, etc. 
It should be noted that impact is defined as the influence on the decisions (regardless of outcome) that shape people's lives, communities, governance, the environment, and elsewhere (Federation for the Humanities and Social Sciences, 2014, p. 9). Impact can be differentiated into positive, neutral or negative as illustrated in Figure 7 (Ahrens \& Zaščerinska, 2014b).

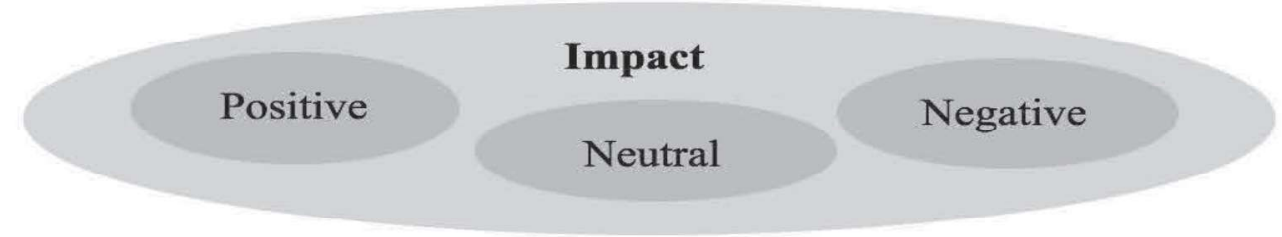

Figure 7. Differentiation of impact

The data were processed by making use of the content analysis (Ahrens et al., 2020). The content analysis was carried out in two phases. The first phase was devoted to the structuring content analysis, and the second phase focused on the summarizing content analysis (Mayring, 2000). The structuring content analysis intends to categorize the data. The structuring content analysis is based on the previously identified criteria (Budde, 2005). The summarizing content analysis is used for reducing the material (Mayring, 2004) for further analysis. The reduction of the material focuses on preserving the essential contents while producing a manageable short text (Mayring, 2004). The data from the carried out survey were categorized in accordance to two criteria. One criterion was the methodology of the present research, namely the development of the system of the external and internal perspectives. The second criterion was the newly elaborated definition of the term "problem" demonstrated in Figure 3.

\section{Results}

In general, all the participants agreed, that they or their institutions experienced restrictions in work life due to the COVID-19 pandemic during the first half of the year 2020. These restrictions took different forms and degree of severity. Two thirds of the respondents (12 participants) suffered from the worldwide ban of travelling. 14 out of 15 experienced, at least temporary, worked from home. The COVID-19 pandemic created the necessity to home-school for the respondents' children: about $33 \%$ of the partners had to manage it. A minority of the respondents dealt with even more severe problems. Three out of 15 respondents had their work contracts or working time reduced due to the crisis, and one needed to quarantine for some time without any working option. Thus, the pandemic affected all the partners' personal and work life in different ways but definitely imposed unprecedented novelties to the management of an international project. The ban of travelling as a general restriction demanded for a significant project restructuring, and a large number of the participants needed to cope with additional tasks such as home-schooling or, as was specified by one person, additional workload due to the overnight switch from the presence to the online teaching formats. All such elements potentially affected the work dedicated to the project. Consequently, the survey revealed that the majority of the partners responding to the survey saw a delay in the progress of the project. While six respondents assumed that the project was delayed significantly, seven respondents saw some delay but were of the general impression that this was manageable. Only one person saw no delay. Being asked, whether the postponement of the presence meetings and the transfer of workshops/conferences into a virtual format affected the project outcome quality, six respondents answered that the outcome quality suffered as an event could not be held as planned. Another four respondents thought that the outcome quality was partially affected because the presence meetings had to be delayed. Nevertheless, online workshops and conferences actually turned out to be a good 
alternative. But still, four respondents were of the opinion that there was no a reduction of quality at all since virtual meetings could equally replace presence activities.

The partners were further asked, whether the effects of the COVID-19 pandemic led to changes in their budget calculation. The question was answered by 10 of the 18 respondents. Among these, seven respondents confirmed no immediate changes although they proposed that there might be effects in the future. The other respodents pointed out that the COVID pandemic's effects together with the project extension until October 2021 did incite the project to serious difficulties. One respondent outlined that there were no means for the reimbursement of the project staff costs within the extended peiod of the project of 12 months: the partner budget remained non-changed while the period for the project implementation was extended. It meant that less budget for the staff costs would remain till the end of the project. Moreover, due to the continuation of the COVID-19 restrictions till Summer 2021, all the remaining activities had to be re-scheduled for the implementation in a shorter time period in 2021. These remarks, although only from the individual respondents, should be taken into account, especially as the pandemic is continuing through the second half of the year 2021.

In summary, it can be stated that the COVID-19 pandemic posed a significant burden on all the project partners and their work within the project. Especially the closure of the partner universities and administrations caused delays in the processes of the study programmes' accreditation and development. As the study programmes' accreditation and development are the main outcome of the project, the progress in the study programmes' accreditation and development has to be monitored closely in the upcoming time period.

Despite the respondents' sceptical outlook on the project performance in the COVIDpandemic, 11 out of 18 respondents were still of the opinion that the project was on a good way to achieve its envisaged objectives. While the granted project extension is understood by several respondents as fundamental in order to achieve the project goal in time, the others pointed out that the COVID-19 pandemic delayed the formal programme approval from the external accreditation agencies in the partner country located in a Third country. One participant revealed that it might lead to a penalty, namely a reduction of the project budget, by the funding organization as originally it was envisaged to have the accredited Master programmes running for at least 12 months period within the course of the project implementation. With the delayed approval, this period would most likely not be achievable. Furthermore, the respondents saw the return to the presence teaching and working on campus while the ongoing pandemic as still critical. That was an issue that might cause further delays and problems in the coming months.

In this line, the effectiveness and efficiency of the project during the first half of 2020 was identified as critical. Nine out of 18 respondents considered the effectiveness and efficiency as generally positive in the project but five respondents did not recognise much or even very limited progress during the past months. That might be due to individual circumstances. Exemplarily, one respondent explained that a project member resigned, leaving a significant gap behind. Further on, the gap could not be filled equivalently.

The communication within the project was considered as generally satisfactory, but certainly improvable. The majority of 10 respondents confirmed that the project partners did get into contact from time to time but only four respondents identified a constant exchange about the project progress. One even expressed the opinion that there seemed to be the partners that had not talked to each other at all, clearly expressing the desire for a more frequent exchange and communication. Nevertheless, almost all the respondents considered the project management to be great (six respondents) or at least good (seven respondents).

Doubts were expressed mostly concerning the timeline of the project. 11 out of 15 respondents admit to be lagging behind a bit. However, they were still confident that they would be able to implement the project on time. In the hindsight, this still optimistic perspective might certainly be questioned due to continuing severe restrictions in the COVID-19 pandemic times. 
Apart from the time issue, 14 out of 15 respondents were still convinced that the project actively contributed to the further development of their institutions and degree programmes. The respondents identified a number of positive effects from the project such as developments in blended learning, partner university benchmarking compared to other institutions, and online opportunities for capacity building of staff members. One emphasized that especially in the light of the recent events, the development and adaption of the degree programmes to a changing world was more relevant than ever. The bi-lateral cooperation agreements between European and Third Country's Universities were also highlighted as the positive outcomes of the project.

Concerning a helpful modification among the cooperation partners, four respondents identified the need to enhance communication with the partners as well as the need to invest more time into administrative tasks than before; otherwise, the invoicing of staff, material, and travel costs would not be completed in due time.

Table 6 presents the findings of the structuring content analysis carried out within the present empirical study.

Table 6.

Findings of the present empirical study

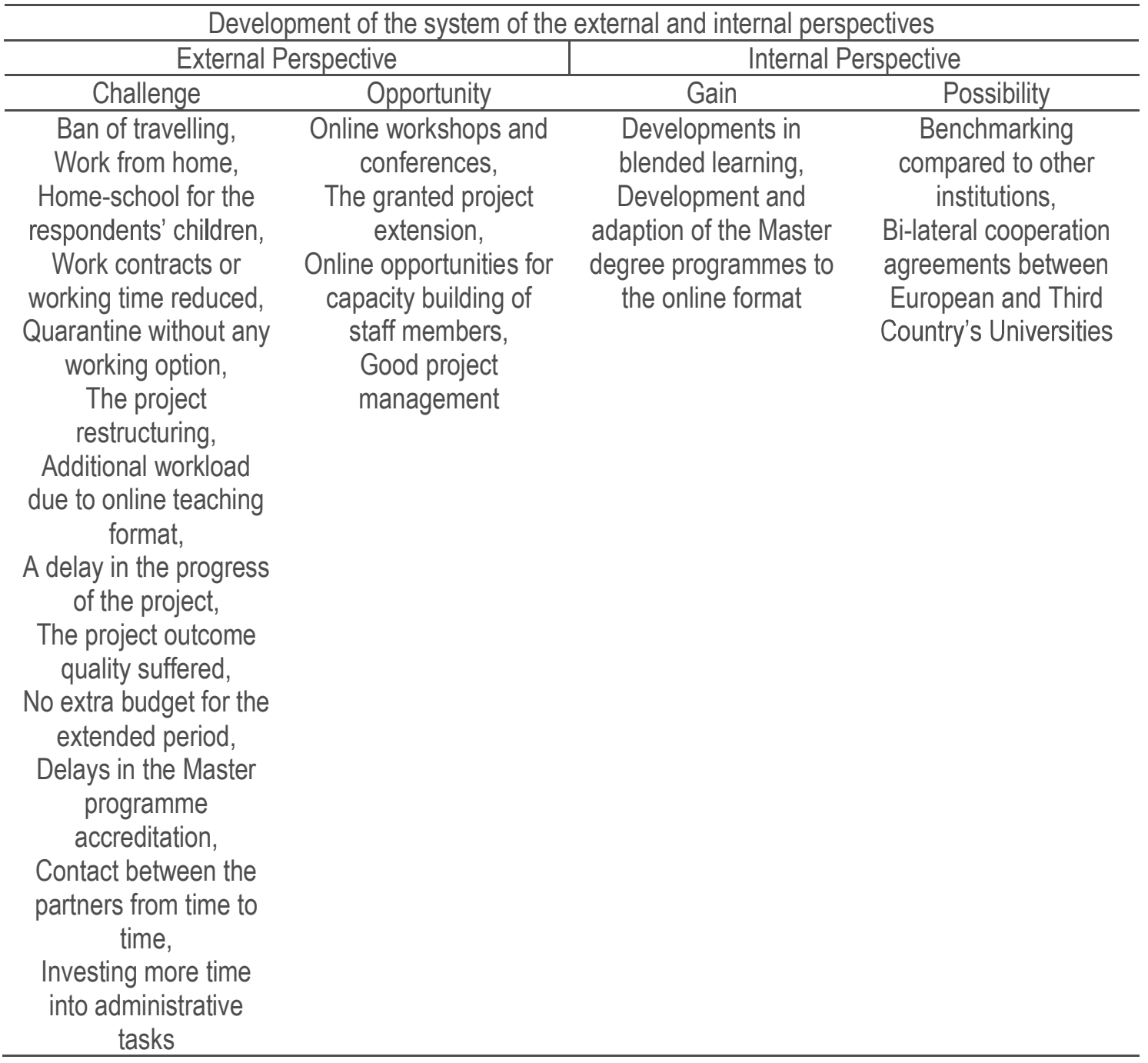

The summarizing content analysis allows finding that the teachers were mostly active in Phase 1 Teachers' professional training and Phase 2 Teachers' professional peer-learning as only a few respondents stressed the gains they obtained within the international project. 
Consequently, Hypothesis 1 is not fully valid for the selected sample. A finding is that the COVID19 pandemic significantly impacted the external perspective of the enhancement of the university teachers' skills in problem-based teaching within the international project as the project participants consider the COVID-19 pandemic as a challenge. Hence, Hypothesis 2 is not valid for the selected sample. Another finding is that the negative impact of the COVID-19 pandemic on the enhancement of the university teachers' skills in problem-based teaching within the international project prevails. Thus, Hypothesis 3 is not valid for the selected sample, too.

\section{Discussion and Conclusions}

The formulated Hypotheses 1, 2 and 3 have not been valid for the selected sample. The assumption on the non-validated Hypothesis 1 is that the average age of the teachers is high (53 years old). This is the age when teachers have already established their professional networks, in comparison to younger teachers who start their careers. Being 53 years old is also the age when the professional development of the teachers conventionally reaches a high level. The teachers in the selected sample probably have learnt the basics of their profession, and now they are interested in the advancement of their professional growth. This is the reason why they focus on the external perspectives (training), in comparison to the external perspective (learning). This assumption serves as the explanation for the non-valid Hypothesis 2 as well. Another issue in regard to Hypothesis 1 is that the teachers' professional development was centred on the process of problem solving, in contrast to the focus on building modules (Lieberman, 2020) or, in other words, the content of the teachers' professional development. Regarding Hypothesis 3, the previous research results revealed that males have a higher level of positive evaluation in comparison to females (Ahrens \& Zaščerinska, 2014b). Against this background, the respondents in the selected sample, being composed of $83.3 \%$ of the male respondents, negatively evaluated the problem solving within the international project. Further on, the previous research related to the relationship between human attitude and age has not been adequately addressed (Ahrens \& Zaščerinska, 2014b). The assumption within the present research refers to the high average age of the respondents, too. The higher the age, the more critisism is conventionally demonstrated by the respondents.

Implications on the enhancement of teachers' skills in problem-based teaching propose to focus on the creation of proper modules of teacher professional development. Another proposal is the great emphasis on the extensive involvement of less experienced teachers into teacher professional development. An implication also is the broader engagement of more females in participation in international projects as part of their teachers' professional development. Widening the professional network of young female teachers could be a priority for the enhacement of teacher professional development, too.

The theoretical research results in the newly defined structural elements of problem solving, namely challenge, opportunities, gain and possibility, analysed within the methodology of the development of the system of the external and internal perspectives. Another theoretical finding is the established relationship between the negative and positive impact and the external and internal perspectives, respectively.

The empirical study results in the finding that the COVID-19 pandemic negatively impacted the enhancement of the university teachers' skills in problem-based teaching within the international project. Another finding is that the COVID-19 pandemic is regarded by the respondents as a challenge. Consequently, the COVID-19 pandemic is an external issue. A finding is that the teachers focus their professional development on Phase 1 Teachers' professional training and Phase 2 Teachers' professional peer-learning. The interpretive paradigm applied to the empirical study' analysis allows drawing a conclusion that the professional development of the participated 
university teachers, being the key actors in teaching problem solving skills to students, has not been enhanced and can be negatively evaluated.

In conclusion, the survey demonstrated a generally positive impression of the project progress but clearly outlines that the pandemic has already had a certain impact on peoples' lives and project work. While the pandemic continues, and the situation may even get worse during 2021, effects may be more significant and could even result in the delay of some deliverables. The project managers should clearly monitor how far the Master programme accreditation and registration with the external accreditation agencies in the partner Third Country or the partner university internal bodies that do not work as supposed due to the pandemic. This might affect the project outcomes as well as time management. Similarly, the respondents clearly encourage the project managers to emphasize the internal communication and exchange in order to stay in contact while presence meetings are not an option.

Thereby, theoretical and empirical findings allow concluding that the paradigm of the professional development aimed at the enhancement of both university teachers' and students' problem solving skills has to be changed from the external problem solving only or regarding a problem as a challenge and opportunity to the problem solving cycle shown in Figure 4. The problem solving cycle proceeds from the external perspective (teaching/training) through the system of the external and internal perspectives (peer-learning) to the internal perspective (learning).

The research has some limitations. The limitation is the inter-connections between the problem solving and the methodology of the development of the system of the external and internal perspectives. Another limitation is the involvement of only one international project's university teachers in the empirical study.

Further research will tend to increase the number of respondents as well as the involvement of participants from different international projects. Enhancement of the proposed methodology and theoretical background will be carried out. Comparative studies of theoretical elaborations and empirical data will attract a lot of research interest in the scientific community, too.

\section{References}

Ahrens, A., Foerster, M., Zaščerinska, J., \& Wasser, I. (2020). European Accreditation Agency's View on Kazakhstan's Engineering and Information Technology Higher Education. SOCIETY. INTEGRATION. EDUCATION Proceedings of the International Scientific Conference. Volume V, May 22nd -23rd, 2020. pp. 15-25. ISSN: 2256-0629. http://dx.doi.org/10.17770/sie2020vol1.4861.

Ahrens, A., Gruenwald, N., Zaščerinska, J., \& Melnikova, J. (2019). A Novel Design of the PreProcessing Stage of Data Mining for Educational Purposes. In Claudiu Vasile Kifor, Norbert Grünwald and Lucian Lobont (Eds), Proceedings of the 9th Balkan Region Conference on Engineering and Business Education (BRCEBE) \& 12th International Conference on Engineering and Business Education (ICEBE) Sibiu, România, 16 - 19 October 2019, pp. 368-376. https://doi.org/10.2478/cplbu-2020-0042

Ahrens, A., Purvinis, O., Zaščerinska, J., Miceviciene, D., \& Tautkus, A. (2018). Burstiness Management for Smart, Sustainable and Inclusive Growth: Emerging Research and Opportunities. IGI Global. Pages: 226. https://doi.org/10.4018/978-1-5225-5442-4.

Ahrens, A., \& Zaščerinska, J. (2010). Social Dimension of Web 2.0 in Student Teacher Professional Development. Association for Teacher Education in Europe Spring 
Conference 2010: Teacher of the 21st Century: Quality Education for Quality Teaching, Riga, Latvia, 7-8 May 2010, pp. 179-186.

Ahrens, A., \& Zaščerinska, J. (2014a). Analysis of Teachers' Use of Web Technologies: Focus on Teachers' Enterprise 3.0 Application. Journal of Information Technology and Application in Education (JITAE) Volume 3, Issue 1 (March 2014), pp. 25-32. http://www.jitae.org/paperlnfo.aspx?ID=12919. doi: 10.14355/jitae.2014.0301.04.

Ahrens, A., \& Zaščerinska, J. (2014b). Students' Attitude to Interdisciplinary Research. Society, Integration, Education. Proceedings of the International Scientifical Conference. Volume I: Higher Education Institutions Pedagogy, School Pedagogy, Pre-School Pedagogy. May, 23th-24th, 2014, pp. 13-23. - Rēzekne: Rēzeknes Augstskolas Izdevniecība, 2014. - p 616. http://www.ru.Iv/ckfinder/userfiles/RAweb/Saturs/zinatne/zinatniskie_instituti/personas _socializacijas_petijumu_instituts/izdevumi/2014/I_DALA.pdf.

Ahrens, A., Zaščerinska, J., Hariharan, R., \& Andreeva, N. (2016). Educators' Opinion on Webinars in Higher Education. Proceedings of the International Scientifical Conference Society, Integration, Education, Volume 1 Higher Education Pedagogy, May, 27th-28th, 2016, pp. 15-27. - Rezekne: Rezeknes Academy of Technologies, 2016. p. 564. ISSN 2256-0629. http://journals.ru.Iv/index.php/SIE. http://dx.doi.org/10.17770/sie2016vol1.1488.

Ahrens, A., Zaščerinska, J., Lange, C., \& Aleksejeva, L. (2021). "A Comparative Analysis of Processes of Conceptual Change for the Enhancement of Implementation of Green Energy Education and Training," International Journal of Information and Education Technology (IJIET) vol. 11, no. 1, pp. 47-51, 2021. http://dx.doi.org/10.18178/ijiet.2021.11.1.1488

Ahrens, A., Zaščerinska, J., Melnikova, J., Ramar, H., Clipa, O., \& Andreeva, N. (2015). Use of Webinars in Higher Education: A Comparative Study of Educators' Experience. Scientific Articles: Applied Research in Studies and Practice, Nr. 11 III International Scientific Practical Conference "Trends in Science and Studies Under Conditions of Globalisation", pp. 22-30. Panevéžys College, Panevéžys, Lithuania.

Bassus, O., Ahrens, A., \& Zaščerinska, J. (2014). Entrepreneurship Education in Engineering Education: Focus on Students' Needs. Proceedings of the 7th International Conference on Engineering and Business Education 13 - 14 October 2014, pp. 69-76. Published by University of Wismar, Germany.

Budde, R. (2005). Mexican and Central American L.A. Garment Workers: Globalized Industries and their economic constraints. LIT Verlag Münster.

Čehlova, Z. (2002). Izziņas aktivitāte mācībās. Rīgā: RaKa.

Cohen L., Manion L., \& Morrsion K. (2003). Research Methods in Education. London and New York: Routledge/Falmer Taylor \& Francis Group.

Eickelmann, B., \& J. Gerick . (2020). "Lernen Mit Digitalen Medien: Zielsetzungen in Zeiten Von Corona Und Unter Besonderer Berücksichtigung Von Sozialen Ungleichheiten [Learning with Digital Media: Objectives in Times of Corona and under Special Consideration of Social Inequities]." Die Deutsche Schule 16: 153-162. http://dx.doi.org/10.31244/9783830992318.09.

European Commission Directorate-General for Education and Culture. (2004). Implementation of "Education and Training 2010" Work Programme. Working Group A "Improving the Education of Teachers and Trainers". Progress Report September 2004. http://ec.europa.eu/education/policies/2010/doc/trainer2004.pdf. 
Federation for the Humanities and Social Sciences. (2014). The Impacts of Humanities and Social Science Research. Working Paper, October 2014. http://www.ideasidees.ca/sites/default/files/2014-10-03-impact-project-draft-report-english-versionfinal2.pdf.

Grabovska, R. (2006). Ilgtspējības principa īstenošana skolotāju izglītībā [Implementation of sustainability principle in teacher education]. Promocijas darbs/ Promotion thesis. Daugavpils Universitāte.

Kacapa, A. (1999). The Professional Humanist Development of Teachers in the Pedagogic Process of the Teacher Training College. Promocijas darba kopsavilkums/ Synopsis of the promotion thesis, Latvijas Universitāte.

König, J., Daniela J. Jäger-Biela \& Nina Glutsch (2020). Adapting to online teaching during COVID-19 school closure: teacher education and teacher competence effects among early career teachers in Germany, European Journal of Teacher Education, 43:4. 608-622, http://dx.doi.org/10.1080/02619768.2020.1809650

Lieberman, M. (2020). Rethinking Teacher Training During COVID-19: Bite-Sized Digital Lessons. Education week. September 24, 2020. Retrieved from https://www.edweek.org/technology/rethinking-teacher-training-during-covid-19-bite-sizeddigital-lessons/2020/09

Mayring, P. (2000). Qualitative Content Analysis. Forum Qualitative Sozialforschung / Forum: Qualitative Social Research, 1(2), Art. 20.

Mayring, P. (2004). Qualitative Content Analysis. In: U. Flick, E. Von Kardoff and I. Steinke (Eds.), A Companion to Qualitative Research (pp. 266-269). SAGE, UK, Glasgow.

Network of International Education Associations (NIEA) (24 July 2020). Statement on the importance of international higher education and research. Retrieved from http://ieasa.studysa.org/wp-content/uploads/2020/07/NIEA-Statement-on-the-importanceof-international-higher-education-and-research.24-July-2020.pdf.

Nunan, D. (1992). Research Methods in Language Learning. Cambridge: Cambridge University Press.

Phillips, D. (2006). Comparative Education: method. Research in Comparative and International Education, Volume 1, Number 4, 304-319, (2006).

Portelli, J. P. (2010). The Challenge of Leading for Equity in Neoliberal Times. Keynote 2. Proceedings of London International Conference on Education September 6-8, 2010, London, UK, Published by Infonomics Society. p. 12.

Robbins, D. (2007). Vygotsky's and Leontiev's Non-classical Psychology Related to Second Language Acquisition. International Nordic-Baltic Region Conference of FIPLV Innovations in Language Teaching and Learning in the Multicultural Context 15-16th June, 2007, Riga, Latvia, p. 47-57.

Sālsberg, P. (2003). Problēmu risināšana un mācīsanās skolā [Problem solving and teaching at school]. Skolotāja rokasgrāmata: aktīvas mācību metodes un demokrātiskas skolas veidošana. R.: Rīgas skolotāju izglìtības centrs.

Sokol, A. (2002). The Thinking Approach. Introductory Information. www.thinking-approach.org. [2008.30.04].

Sokol, A. (2007). Development of Inventive Thinking in Language Education. Synopsys of the PhD Thesis. University of Latvia. 
Tilla, I. (2003). Development of adolescents' social culture competence within the second foreign language studies. Synopsys of the PhD Thesis. University of Latvia, Riga, Latvia, p. 24-42.

Tillıa, I. (2005). Sociālkultūras mācišanās organizācijas sistēma. RaKa.

Vigotskis, L. \{Vygotsky]. (2002) Domāšana un runa. [Thought and Language]. Izdevniecība „EVE” Rīga.

World Economic Forum. (2020a). Global Gender Gap Report 2020. ISBN-13: 978-2-940631-032Retrieved from http://www3.weforum.org/docs/WEF_GGGR_2020.pdf.

World Economic Forum. (2020b). The Future of Jobs Report 2020. World Economic Forum. $\begin{array}{llll}\text { October } & 2020 . & \text { Retrieved }\end{array}$ http://www3.weforum.org/docs/WEF_Future_of_Jobs_2020.pdf.

Zaščerinska, J. (2010a). Professional Environment for Teacher Professional Development. Proceedings of 5th International scientific conference Theory for Practice in the Education of Contemporary Society of Riga Teacher Training and Educational Management Academy, 25 - 27 March 2010, pp. 396-402. Riga, Latvia.

Zaščerinska, J. (2010b). Conditions for Student Teacher Professional Development. Proceedings of the Teacher Education Policy in Europe (TEPE) Conference 2010 Developing Quality Cultures in Teacher Education: Expanding horizons in relation to quality assurance, 30th September- 2nd October 2010, pp. 20-32. Tallinn University, Estonia. http://tepe.files.wordpress.com/2011/01/tepe-2010-conference-proceedings.pdf.

Zaščerinska, J. (2010c). English for Academic Purposes Activity in Language Education. In: Sanita Madalāne (Ed.), Proceedings of the 5th International Conference of Young Scientists of Riga Teacher Training and Educational Management Academy, the 10th December 2009, pp. 209-217. Riga: Riga Teacher Training and Educational Management Academy, 2010, Latvia.

Zaščerinska, J. (2011). A Historical Perspective on the Development of the Concept Competence. In: Sandra Laizane (Ed), Proceedings of the 14th Students' Conference „We in Time, Space and Development" of Rezekne Higher Education Institution Faculty of Humanities and Law May 13, 2010, pp. 75-86. Rēzekne: Rēzeknes Augstskolas Izdevniecība 2011, Latvia.

Zaščerinska, J., \& Ahrens, A. (2010). Social Dimension of Web 2.0 in Teacher Education: Focus on Peer-Learning. Proceedings of London International Conference on Education September 6-8, 2010, London, UK, pp. 182-187. Published by Infonomics Society.

Zaščerinska, J., \& Zaščerinskis M. (2012). Problem Solving in Student Police Officers' Professional Development. Proceedings of the I International scientific conference "Legal, Sociological and Psychological Aspects of Human Safety" of State Police College, January 28th, 2011, pp. 251-262. State Police College, Riga, Latvia.

Žogla, I. (2007). Didaktika humānpedagoǵijā [Didactics in human padagogy]. Latvijas Universitātes Pedagoǵijas un psiholoǵijas fakultātes „Augstskolu didaktika: mūsdienu teorija un prakse" kursa lekcija 2007. gada 12. februārī.

Лобанов, А. (2004). Основы профессионально-педагогического общения [Basics of professional pedagogical communication]. Москва Academia.

Мельникова, А. (2003). Язык и национальный характер [Language and national character]. Речь. 
The Impact Of Covid-19 On The Improvement Of Teaching SKills On Problem-Based Learning (PbL)

Панов В. И. (2007). Психодидактика образовательных систем. Теория и практика [Psychodidactic of educational systems. Theory and practice]. ПИТЕР. (in Russian)

Сорокин, Н. А. (1974). Дидактика [Didactics]. Издательство "Просвещение” Москва. 